日本の伝統的民家における小屋組荷重の伝達部材からみた軸組構成の系統的記述 木造軸組構法の空間構成に関する方法論的研究 その 3

\title{
SYSTEMATIC COMPREHENSION OF FRAMING FORMATION FOCUSSING ON THE MEMBERS SUPPORTING ROOF LOAD IN JAPANESE TRADITIONAL TIMBER HOUSES
}

Methodological studies in the spatial composition of wooden framework systems Part 3

\author{
堀江 亨* \\ Tooru HORIE
}

\begin{abstract}
This paper aims to grasp the framing systems in Japanese traditional timber houses. According to the transfer routes of roof load, diversities of directions and the number of supporting members are defined. Ranking the arrangement of transfer routes whether in the core structure or in the outer structure hierarchically, various reasons of the more or less of supporting members are clarified as compared with the displacement through the framework. Analyzing the composition of transfer routes for each house, it's revealed that the characteristics of framing systems are determined by two factors ; one is the potential of spatial expansion between core and outer structure, the other is the complication of framing formation such as piles of beams, girders and posts.
\end{abstract}

\section{Keywords: traditional timber house, framing systell, transfer route of roof load core structure, outer structure 伝統的民家，架構法，荷重経路，上屋，下屋}

\section{1. 序}

本研究は、日本の伝統的民家における架構法を系統的に記述する ことにより、軸組構法から生ずる空間の構成原理を明らかにするこ とを目的としている。分析対象は、近世初頭以降に建設された垂木 構造または双首構造による草蒀農家の軸組架構とする。分析の範囲 は、上部の小屋組が載る範囲である上屋と、その周辺の下屋により 構成されている柱・梁の主架構部分を扱う。

前編までの経過は、まず初編1ににおいて、構成材の配置に関わる 述語を定め、軸組における横架材の名称と位置を規定した。次いで 前編 ${ }^{2}$ では、小屋組の荷重を受けている横架材の位相を、その高さ と水平領域の諸区分により分類し、横架材の配置の多様性を類型化 した。前編の分析では、個々の横架材が占める位置については扱つ たが、どのような部材の組み合わせによって小屋組の荷重を下部に 伝達しているのかという点には言及しなかった。伝統的民家におい ては屋根を支える架構方式が多彩で、小屋組の荷重のかかる点を逐 一柱で支える場合もあれば、梁組の技巧により荷重がかかる点とは 無関係な位置の柱に支持させる場合もある。またこの方式の違いが、 地域に固有の架構法を特徵づけている。

本編は、小屋組の荷重(以下、単に荷重とも呼ふ)を支持する軸組 架構の複雑さを、構成部材の集積として系統的に把握することを目
的とする。荷重を伝達するために働く軸組の柱・梁などの部材の連 なりを荷重経路と呼び、荷重が軸組部材を材軸方向に伝達すること により荷重のかかる位置に変化が起こるときに、荷重が移動すると いうことにする。本編では、荷重経路において荷重が移動する方向 と、荷重を伝達するために費される部材数の関係に着目する。

分析対象として、本編では、前編で扱った 35 棟のうち、異なる 地域において「〜造り」「〜建て」のような固有の架構法が用いら れている 17 地域(図-1)の代表例各 1 棟と、中世に遡る民家 1 棟の、 計 18 棟(表-1)を取り上げた。

\section{2. 荷重経路の記号化}

図-2 は、架構と間取りの関係を例示したものである。双首、小 屋束などの小屋組部材の下端が軸組に載る点を荷重点と呼ぶことに すれば、この事例では、双首の脚部が載る上屋境の荷重点 18 箇所 と、小屋束が立つ上屋内の荷重点 6 箇所の、計 24 箇所の荷重点に 荷重がかかっている。荷重経路(以下、単に経路とも呼ぶ)とは、荷 重点を起点として柱に到達するまでの支持部材の連なりを、一筆書 きの路線としてとらえたものである。

たとえば、図-2の荷重点1にかかる荷重は、上屋梁アの上に載 り、束を経て踒梁イを経由し、上屋柱 $\mathrm{A}$ と下屋柱 a に到達してお
* 日本大学生物資源科学部森林資源科学科 尃任請師 ·博士 (工学)
Lecturer, Dept. of Forest Science and Resources, College of Bioresource Sciences, Nihon Univ., Dr. Eng. 
り、荷重経路は 2 経路となる。荷重点 2 にかかる荷重は、上屋桁ウ、 繋梁工を経て前後に分かれてのち、下屋析才を経由し下屋柱 $\mathrm{b}, \mathrm{c}$ に至り、また慗梁力を経て上屋柱 $\mathrm{B}$ と下屋柱 $\mathrm{d}$ に至っており、計 4 経路を抽出できる。また荷重点 3 は、地棟キと上屋梁クの交点上 に載るため、荷重はそれら両者の左右に分かれ縱横に組まれた梁組 を経由し、C, D, E, e, f の5本の柱に到達している。荷重点 3 から の経路は前二者よりもさらに複雑かつ多岐になる。

図-3 は、こうした多様な荷重支持形式を把握するために、荷重 が移動する方向と、荷重伝達に費された部材数により、図-2 の荷 重点 $1,2,3$ からの荷重経路を抽出し、以下の手順により記号化した ものである。荷重の移動方向については、本研究の初編で定義した 方向成分を用いる ${ }^{3)}$ 。すなわち、水平方向には、上屋内を移動する $\mathrm{X}$ 、上屋境を移動する $\mathrm{Y} 、$ 下屋内を上屋境と直角方向に移動する $\mathrm{x}$ 、 下屋内を上屋境に平行に移動する $\mathrm{y}$ を定める。垂直方向には、上屋 内ないしは上屋境を移動するZ、下屋を移動する z の各成分を定め る。なお、横架材による水平移動、束による垂直移動のいずれも生 じない場合には、方向成分 $\phi$ を用いる。また、荷重が経由した横架 材、垂直材の総数を経由部材数と呼ぶことにする。なお本研究では、 軸組と小屋組の関係に主眼をおき、柱を荷重経路の到達点と見なす。 このため、柱から土台、礎石を通じて地面に伝わる経路は考虑しな い。

この原則により、方向成分と経由部材数により荷重経路を表記す る。たとえば、荷重点 1 から下屋柱 $\mathrm{a}$ に至る荷重経路 R 12 は、上 屋境において垂直に荷重が移動した Z、上屋境から下屋側に移動し たxにより構成され、荷重が経由する部材は、上屋梁・束・繋梁・ 下屋柱の 4 部材であるから、Zx4 と表記する。また、荷重点 3 から 下屋柱 $\mathrm{f}$ に至る荷重経路 R31 のように折れ曲がりの多い経路では、 荷重の移動した方向は順に X, X, Z, X, $\mathrm{x}$ であるが、同じ方向成分を 一度だけ用い、経由部材数を逐一数えるものとし、XZXx と表す。 これは、荷重伝達における方向成分の種類と費された部材数を、そ れぞれ明確化する意図による。なお、荷重点 3 から上屋柱 C に至 る経路には、異なる部材を経由して同一の柱に到達する R33, R35, R36があるが、これらは個々の経路として扱う。それゆえ複雑な架 構ほど経路は長く、しかも経路数が多くなる。このようにして、荷 重点 3 を起点とする荷重経路は 10 経路抽出でき、XZx5, XZ5, X3
の3 種類の表示形式に分類される。

\section{3. 荷重経路の分類}

(1) 方向成分と経由部材数による分類基準

図-4a，4b は、上に述べた手続きにより、18 棟の民家の全荷重点 からの荷重経路を抽出し、分類したものである。図-4a は双首すな わち上屋境を起点とする荷重経路を、図-4b は小屋束すなわち上屋 内を起点とする荷重経路を示している。それぞれのタイプには部材 構成を併せて例示し、また該当する経路数を分析対象 18 棟につい て累計し、枠内に記している。

縱軸に示した経由部材数は、架構の複雑さを示す指標であり、横 軸に示した方向成分の組み合わせは、上屋・下屋の領域間における 部材配置の多様性を示す指標である。とくに横軸については、方向 成分が X, Y, Z 範囲内で表され荷重経路が上屋内に収まる上屋構 造と、方向成分に $\mathrm{x}, \mathrm{y}, \mathrm{z}$ が加わり下屋にまで荷重が移動する下屋

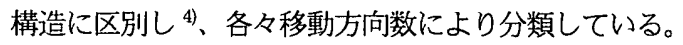

上屋構造に属する方向成分 $\phi に は 、$ 荷重点の直下に横架材を介し て上屋柱が立つ構成が相当する。柱勝ちの場合には経由部材数は少 なく、梁勝ちの場合ほど経由部材数がより多くなる。方向成分 $\mathrm{X}$ は、上屋内の梁行もしくは桁行方向に横架材により荷重が移動する 場合を示す。方向成分 Y は、上屋境に沿った移動を示す。それゆ え小屋束すなわち上屋内の荷重点からの経路(図-4b)では、Y は単 独では成立しえない。方向成分 Z は、荷重が上屋内もしくは上屋 境の垂直方向に移動したのちに柱に至るものであり、束と管柱を用 いた構成が相当する。本編でとりあげた民家では Z が単独で現れ た経路は見られなかった。方向成分 $\mathrm{XY}, \mathrm{XZ}, \mathrm{YZ}, \mathrm{XYZ}$ は、上記の 単独成分が組み合わされた荷重移動を示す。ここまで述べた上屋構 造に属する方向成分は、ある上屋柱を省略するために、別の上屋柱 に荷重を移す構法である。

一方、下屋構造に属する方向成分 Zx は、上屋柱を略すために下 屋柱に荷重を伝える最も単純な構法であり、下屋に張り出した横架 材に束立てした構成が相当する。これには図-4b の小屋束からの経 路は対応しえない。方向成分 XZx, YZx, XYZx は、Zxに見られる 部材構成が架構の内寄りで一歩進んだ形式であり、下屋からより遠 い上屋内の小屋束の荷重を下屋柱に伝えることを可能にしている。

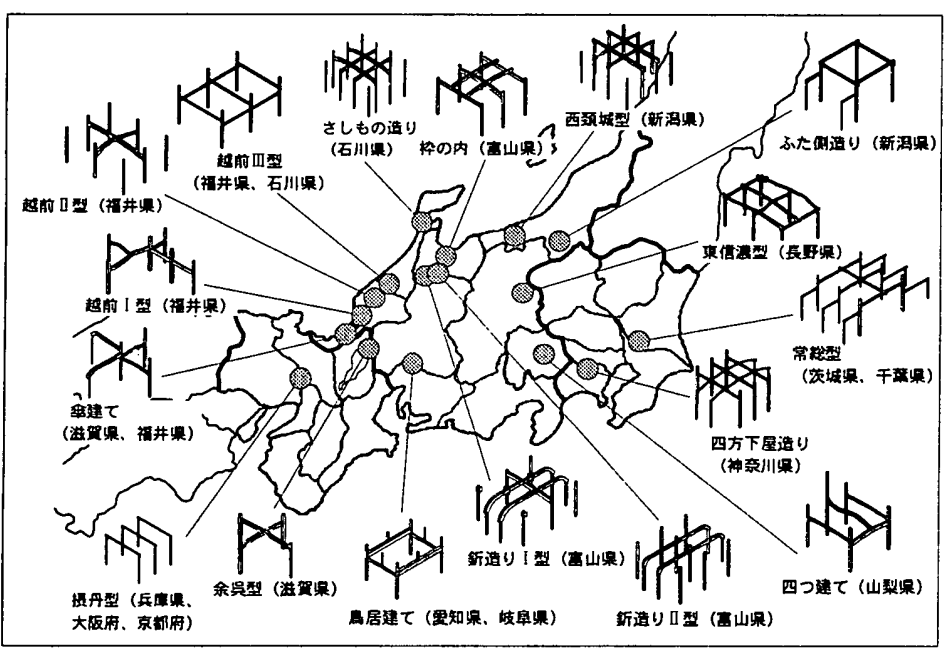

図-1 架構法の分布

\section{表-1 分析対象民家}

\begin{tabular}{|c|c|c|c|c|}
\hline 住宅名称 & $\begin{array}{l}\text { 建設年代 } \\
\text { (世紀/年) }\end{array}$ & $\begin{array}{l}\text { 所在地 } \\
\text { (当初) }\end{array}$ & 小屋組形式 & 架構法名称** \\
\hline 古井家住宅 & 16 後半 & 兵庫県 & 双首十棟束 & \\
\hline 上野家住宅* & 17 初 中 & 山梨県 & 立垂木十棟束 & 「四つ建て」 \\
\hline 泉家住宅 & 17中～末 & 大阪府 & 船垂木十棟束 & <攝丹型 $>$ \\
\hline 坪川家住宅 & 17中〜末 & 福井県 & 双首 & $<$ 越前回型 $>$ \\
\hline 推名家住宅 & 1674 & 茨城県 & 投首十棟束 & 《常総型》 \\
\hline 北村家住宅 & 1689 & 神奈川県 & 双首+槙束 & 「四方下屋造り」 \\
\hline 春原家住宅 & 17末 & 長野県 & 双首+棟束 & 《東信渒型》 \\
\hline 昢口家住宅 & 18 初 & 福井県 & 双首 & $<$ 越前 I 型 $>$ \\
\hline 牧村家住宅 & 18 初 & 岐阜県 & 双首 & 「鳥居建て」 \\
\hline 佐藤家住宅 & 1738 & 新潟県 & 双首 & 「ふた側造り」<魚沼型〉 \\
\hline 座主家住宅 & 18 初 中 & 石川県 & 双首 & 「さしもの造り」〈能登 I 型 $>$ \\
\hline 江向家住宅 & 18 初〜中 & 富山県 & 双首 & 「釿造り」I＜五筬山川型> \\
\hline 橋本家住宅 & 18 初 中 & 福井県 & 双首 & $<$ 越前 II 型 $>$ \\
\hline 宮地家住宅 & 1754 & 澻賀県 & 双首 & <余呉型 $>$ \\
\hline 山下家住宅* & 18中 & 福井県 & 双首 & 「金建て」〈大浦型〉 \\
\hline 佐伯家住宅 & 1768 & 富山県 & 双首 & 「势の内」 \\
\hline 山口家住宅 & 1779 & 新㳷県 & 双首 & <西䅡城型> \\
\hline 野原家住宅* & 18末 & 富山県 & 双首 & 「釿造り」 I <五箇山 I 型> \\
\hline
\end{tabular}

住宅名の無印は、国指定重要文化財。*は府県指定文化財。

**「」は地場呼称、〈〉は既往研究報告上の名称、《》は本研究上の仮の名称 
方向成分 Zxy, YZxy は、それぞれ Zx, YZx に見られる構成が下屋 においてさらに展開したものである。これにより下屋柱の位置を変 える自由が生じる。上屋隅部にかかる荷重(隅垂木や隅双首)は、と くに Zxy に対応する。なお方向成分 XZxy は、本編で扱った民家 には見られなかった。また、方向成分 Zxyz, YZxyz は、Zxy, YZxy

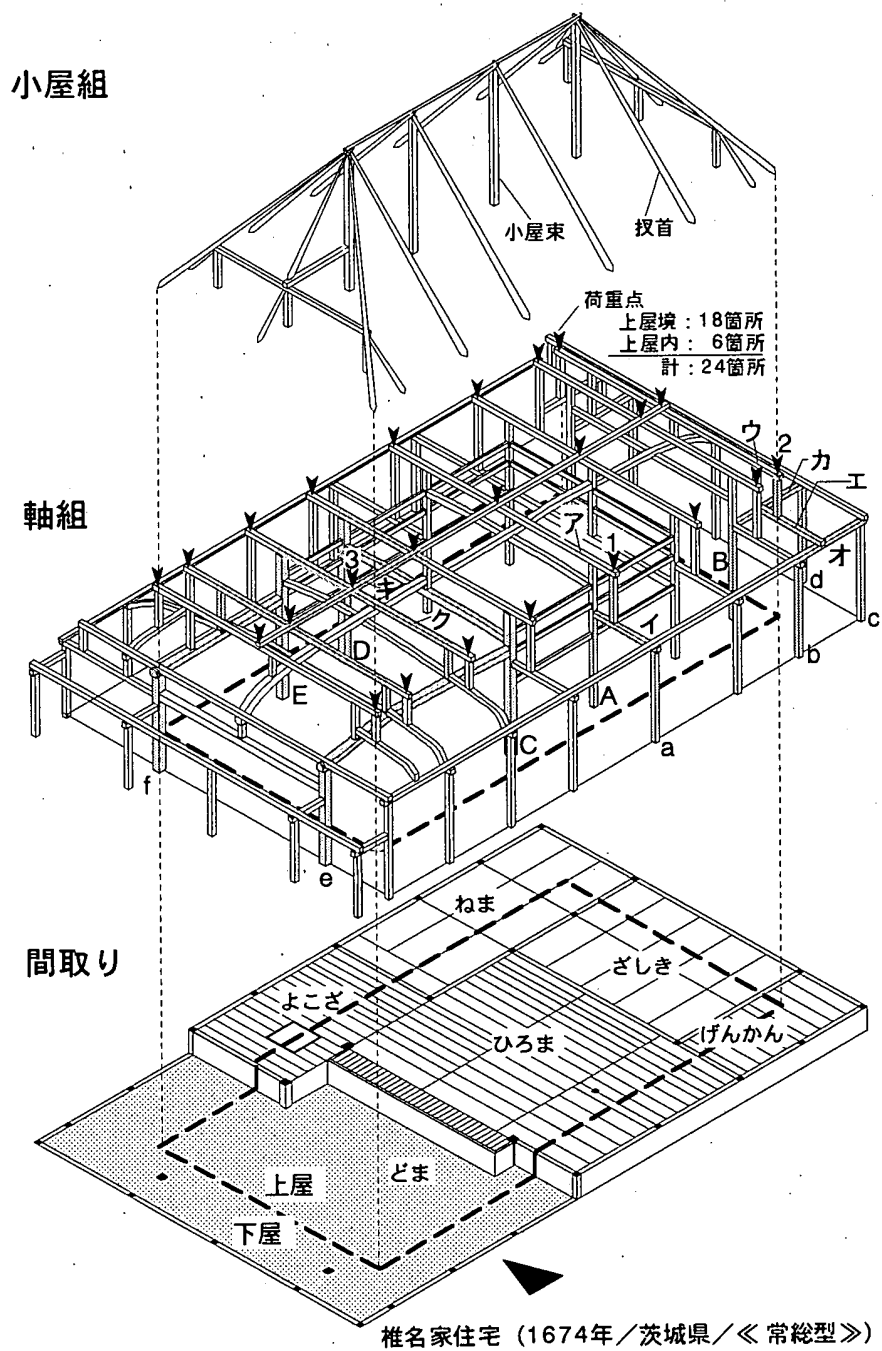

図-2 架構と間取りの関係

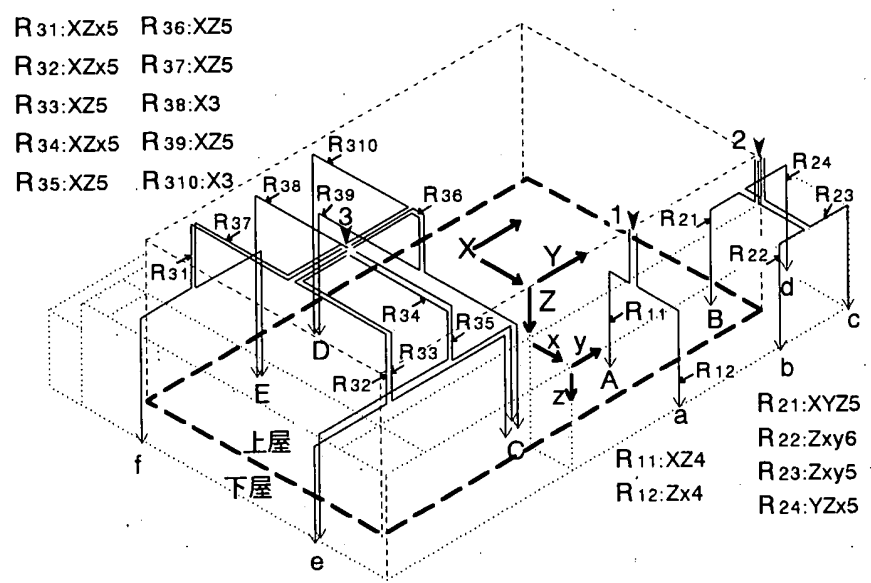

図-3 荷重経路の記号化
がさらに発展した形どして、下屋における重直方向の荷重移動が加 わつたものである。これは上屋と下屋にそれぞれ束を配して荷重を 伝達するので、上屋、下屋間に横架材が多重化しなければ対応でき ない構成である。以下、方向成分の組み合わせにより、最も複雑な XYZxyz までのうち、対応する経路と部材構成を図示した。

(2) 荷重経路の標準型の設定

図-4a，4b における移動方向数と経由部材数の対応を見ると、概 して移動方向数が増すほど、経由部材数が多くなる傾向が見られる。 これは、上屋という限られた範囲で荷重を処理する上屋構造に比べ、 上屋・下屋にまたがったより広範囲を利用した下屋構造の方が架構 配置が多角化し、空間的にも高次元化するので、それに応じてより 多くの部材数を要するという見方により説明できる。ただし、図上 の分布はある程度の広がりをもっており、その分布上の位置の相違 は構法上の技法と関連していると考えられる。

こうした架構と空間の関係を評価するために、標準的な小屋組の 支持形式を次のように考える。図-5 に示すように、小屋組の受け 口の部位で、双首をその両端で受ける上屋梁が双首台となるか、あ るいは小屋束を束列に沿って配した束踏で受け、荷重は経由するが 荷重移動が生じない形式を想定し、柱に至るまでの荷重経路におい て一部材あたり一方向の荷重移動が行われると仮定する。この場合 の経由部材数 $\mathrm{t}$ は、移動方向数 $\mathrm{d}$ に、双首台または束踏の分 $(+1)$ と、 柱の分 $(+1)$ を加えた值となる。この $\mathrm{t}=\mathrm{d}+2$ という関係が成り立つ ような荷重経路を標準型と呼ぶことにする。図-4a，4b では標準型 の経路を、とくに太い枠で囲んでいる。

以下、標準型に比べ移動方向数に対する経由部材数が少ない経路 を部材過少型、多い経路を部材過剩型と呼び、各々に生じている構 法を考察する。

（3）部材過少型の荷重経路に生じている構法

小屋組と直接取り合う部位では、標淮型における双首台を省略し、 双首尻を上屋桁で直接受けている形式が見られた(図-4a: $\mathrm{Y} 2, \mathrm{XY} 3$ な ど)。これを「桁受けりと呼んでおく。一方、小屋束を受けるため に束踏を略し、上屋梁で直接小屋束を受けている形式が見られた(図 $-4 \mathrm{~b}: \mathrm{X} 2, \mathrm{XZx} 4$ など)。これを「束踏抜きり呼んでおく。これら両 形式は、軸組と小屋組の取り合う部分に一般的に生じうる部材構成 である。

これに対して、2 万向の荷重移動を得るために 1 部材で済ませた 形式として、図 4-a の YZxy5 に示すような「釿梁」を用いた構法 があうた。これは、上屋の垂直成分 Z の移動と、上屋境と直角に 下屋に移動する成分 $\mathrm{x}$ の移動を、曲がった材を利用して同時に行い、 束を省略したものである。また、図 4-a の Zxy4に示すような「投掛 梁」を用いた構法では、上屋隅にかかる荷重を下屋の隅柱まで一気 に移動するために梁を斜めに挂け、荷重移動 $\mathrm{x}, \mathrm{y}$ を同時に行なっ ている。こうした梁を用いた支持形式は、上屋・下屋間の空間を一 体化するための下屋構造の技巧として、局所的に見られる構法と考 えられる。

一方、柱に関する構法として、図 4-a の YZx2 や YZx3 に見られ る「父柱」を用いた納まりがある。杈柱は下屋に立つ柱でありなが ら、枝分かれした部分で上屋の荷重を直接受けることにより梁と束 を省略したものである。この構法は、上述した梁構法と同様に下屋 構造の一種としてとらえられる。これとは別に、柱を用いた構法と 
して「棟持柱」による架構が見られ、図-4b において $\phi 0$ と表記し た。すなわち小屋組部材が通し材となってそのまま地面に到達して いるので、他に軸組部材を必要としないという解积から、経由部材 数を 0 と見なした。同様に部材数を少なくすませている構法が、図 $-4 \mathrm{~b}$ の XZ2 に示した「棟束」を用いた形式にも見られる。

（4）部材過剩型の荷重経路に生じている構法

小屋組と直接取り合う部位では、上屋梁の端部を直接柱で受けず、 その間に栴を付加した「京呂」(図-4a: $\phi 3, \mathrm{X}_{4}, \mathrm{Y}_{4}$ なと)とすれば、 経由部材数は標準型よりも 1 部材多くなる。なお、この納まりは 下屋においても生じている(図-4a:Zx6, Zxy6など)。

また、横架材の接点において、その直角方向あるいは同方向に梁、 桁を重ねた構成(図-4a: $\phi 4, \mathrm{XZ7}, \mathrm{YZ} 6$ など)が見られる。これを「十 字梁」もしくは「重称」と呼んでおく。これとは別の形態として、 同じ移動方向に対して 2 部材以上の横架材を費した形式がある。 たとえば図-4a の XYZ7 では、同方向Yへの荷重移動のために高さ の異なる二段構えの梁が用いられている。これを「段梁」と呼ん でおく。

一方、柱を用いた過剩型としては、図-4a の YZ6 のように、柱が 「管柱」となって軸組上端まで届かず、胴差を介して束を重ねた形 式がある。

こうした部材数の多い荷重経路は、上に挙げた構法が単独に用い られたものよりも、いくつかの構法がからみあって実際の軸組を形

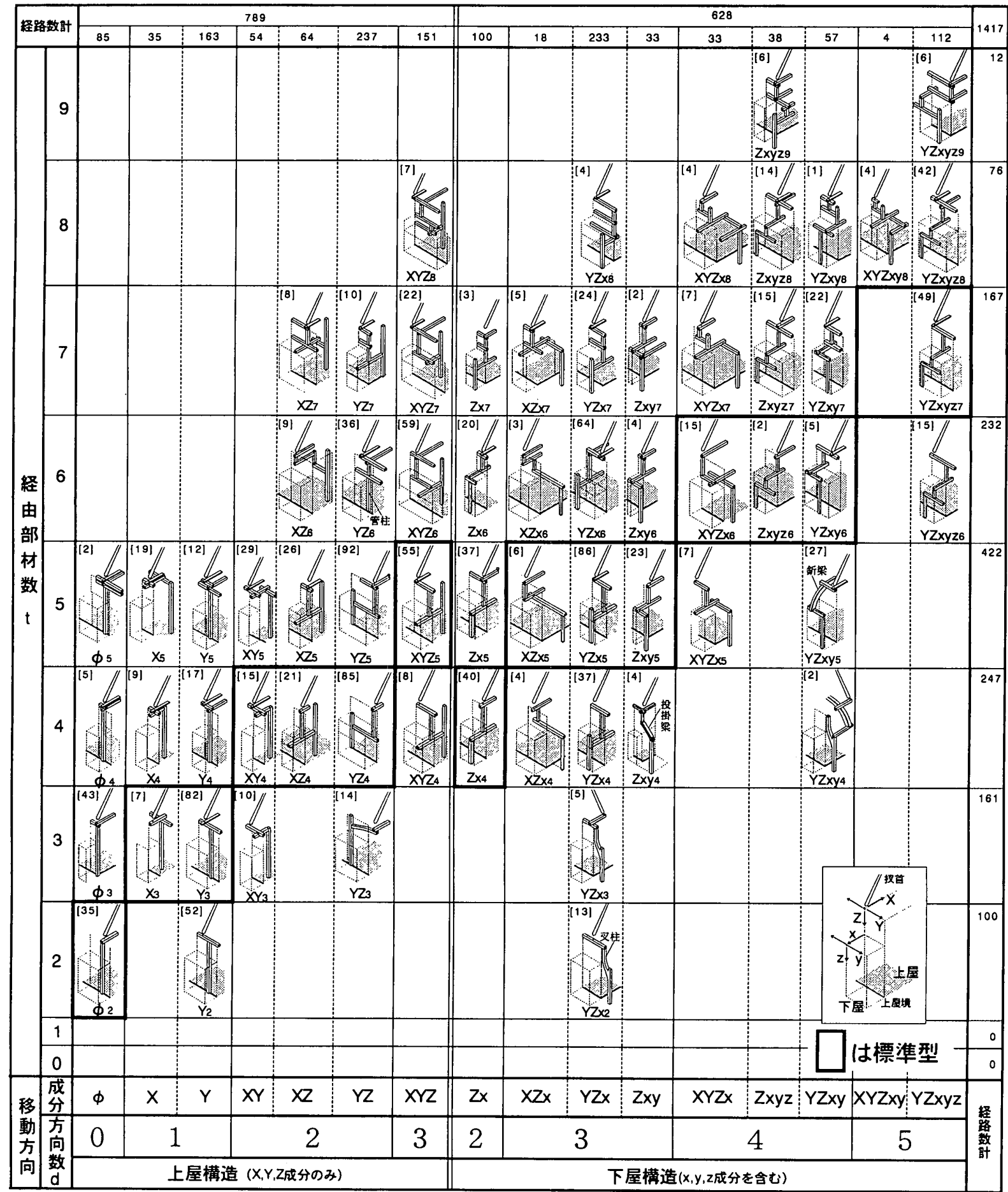

図-4a 双首(上屋境荷重点)からの荷重経路の分類 
成している。そのために、移動方向数に対して経由部材数が著しく 多い形式が現れている。ただし、多部材を費し複雑な構成をとる荷 重経路は、図-4a の Zx9 や Yzxyz9のような下屋へ荷重を移動する ものばかりでなく、XYZ8 のように上屋内に経路が収まる場合でも 現れている。

\section{4. 荷重経路の集合形式からみた架構の類型化 \\ (1) 架構類型の抽出方法}

民家における 1 棟の架構は、様々な軸組構成が集約されて成り立 っている。表-2 は、以下の 2 つの観点から各棟の経路数の内訳を 求め、架構の特性を類型化する過程を示したものである。

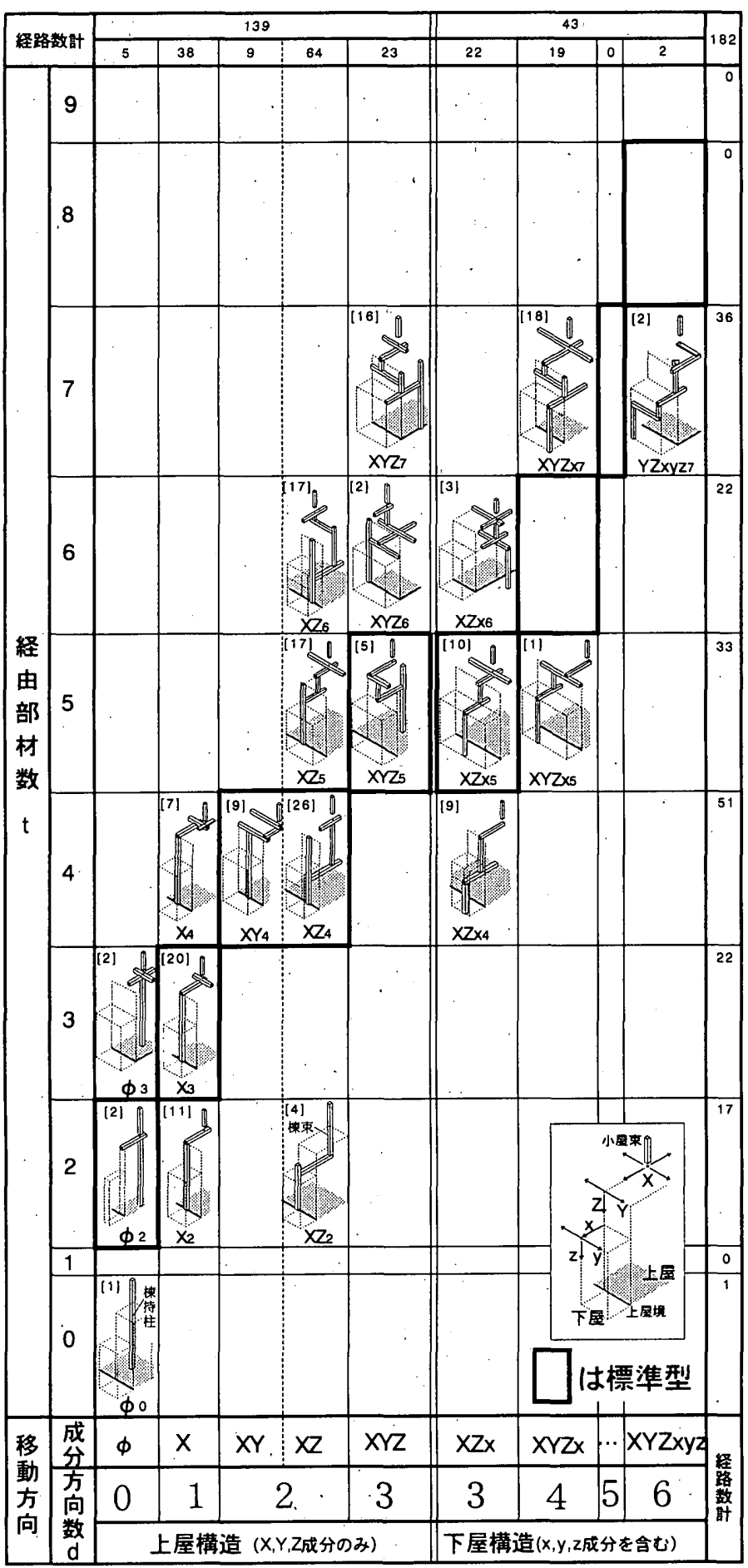

図-4b 小屋束(上屋内荷重点)からの荷重経路の分類
まず、荷重経路の到達点による内訳として、全経路数 $\mathrm{N}$ に対し て到達範囲が上屋内に収まる経路数 nc、下屋に至る経路数 no およ び、下屋到達率 $\mathrm{no} / \mathrm{N}$ を揭げた。これを荷重伝達における下屋構造 の割合と見なす。実際の架構では、すべての荷重点に対して下屋構 造が生じるのではなく、部屋境などでは上屋柱に荷重を受け持たせ る場合もある。そこで、下屋構造の発達の程度を判断する指標とし て、下屋到達率が $1 / 3$ 末満のものを $\mathrm{a} 、 1 / 3$ 以上のものを $\mathrm{b}$ とする。 $\mathrm{a}$ が比較的上屋構造が卓越する架構、 $\mathrm{b}$ が比較的下屋構造が発達し ている架構である。

次に経由部材数の多寄に関して、移動方向数 $\mathrm{d}$ と経由部材数 $\mathrm{t}$ の関係により経路数の内訳を求めた。本研究では、標準型の経路に おける移動方向数と経由部材数の関係 $\mathrm{t}=\mathrm{d}+2$ を指標とし、標準型 に比し経由部材数が 1 少ないものから 2 多いものまで、すなわち $\mathrm{d}+1 \leqq \mathrm{t} \leqq \mathrm{d}+4$ の関係が成り立つ経路が集合した架構を、経由部 材数の点で中庸を得た形式であると見なし、0で表す。その根拠を 述べると、標準型では移動方向に数えていない双首台、束踏が省略 されれば、標準型よりも 1 少ない経由部材数となる。また逆に、 標準型の前提である折置に対して、桁が追加され京呂に置き換われ ば、移動方向数は变わらずに経由部材数が 1 増える。同様に、荷 重移動の途中で十字梁の交点で上部荷重を受ける場合、その下梁に 伝わる経路では、上梁の通過により移動方向数は変わらずに経由部 材数が 1 增える。これら 3 つの構法は、民家においてしばしば起 こるものであり、梁組の特異性を反映するものではないと考えられ るためである。そして、上に述べた経路よりも移動方向数に対する 経由部材数が相対的に少ないもの、すなわち $\mathrm{t} \leqq \mathrm{d}$ となる経路が 存在する架構を一とする。また、相対的に経由部材数が多く $t \geqq$ $\mathrm{d}+5$ となるような経路が存在する架構を+とする。

こうして設定した、荷重到達範囲による分類 $\mathrm{a}, \mathrm{b}$ と、経由部材 数の多寡による分類一, $0,+$ ，組み合わせにより、表 -2 の最右列に 架構類型を示すとともに、図-6 に各類型の分布範囲を模式的に揭 げた。

\section{(2) 架構類型の特性}

図-7は、上述した架構類型の代表的な例を分析対象から 1 棟ず つ選び、その架構の全容を揭げ、経由部材数の多寡を生じさせてい る構法を付記したものである。併せて、1 棟における荷重経路の集 合形式を経路集計式として揭げた。この多項式の係数は、同種の経 路の数を表している。
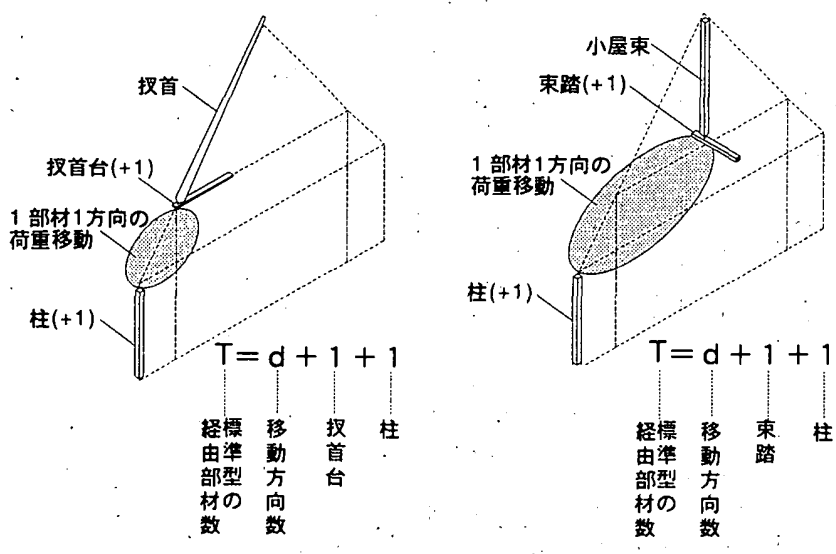

図-5 荷重経路の標準型の考え方 
架構類型 a 0 は、上屋構造が卓越しており、なおかつ移動方向に 対する経由部材数が標準型に近い荷重経路により成り立っているも ので、荷重支持に費される部材が中庸を得ていると評価できる。こ のなかで最も素朴な部材構成として揭げた古井家住宅では、平側の 荷重点 1 から上屋柱 $\mathrm{A}$ に至る経路 $\phi 2$ 、および上屋内の荷重点 2 か ら上屋柱 B に至る経路 X 3 が標準型となっている。また、妻側の荷 重点 3 から上屋柱に C に至る経路では、桁受けとしているために 標準型よりも 1 部材少なくなっている。この架構では、すべての 荷重経路が上屋内に納まり、下屋は構造的に上屋と連続していない。 また、経路集計式がわずか 3 項で成り立っていることにも表われ ているように、小屋組の荷重を受けるための軸組構成がきわめて単 純かつ規則的になっている。

以下に述べる諸類型は、架構の一部に a 0 に用いられる納まりを 残しつつ、他の部分において a0 をもとにして発達した荷重支持形 式の組み合わせとして理解できる。

架構類型 bo は、a の荷重移動が多様化したものである。例として揭げた牧村家住宅で は、荷重点 4 を上屋柱 D で受ける形式は a 2 と類似しているが、 5 から下屋柱 e に至る経路 Zx5、6 から下屋柱 $\mathrm{f}$ に至る経路 $\mathrm{YZx} 6 、 7$ から下屋柱 $\mathrm{g}$ に至る経路 Yzxy7 などの様々な下屋構造が生じてい る。この類型に特徴的なのは、京呂や十字梁の交点に荷重がかかる などの構法による部材数堌は若干あるが、いずれも標準型とほぼ同 等の部材数で賄っていることである。

架構類型 $\mathrm{a}^{-}$は、 $\mathrm{a} 0$ における上屋構造の優越を保ち、小屋組の荷 重を受けるための部材数を減らして対応したものである。例として 揭げた上野家住宅では、上屋境の荷重点 8 から上屋柱 $\mathrm{H}$ への経路 は a o の性状に倣うが、棟通りの荷重支持の仕方が著しく異なって いる。たとえば、棟持柱を用いた経路は $\phi 0$ は、荷重点 9 と到達点 I が同一部材であり、小屋組の荷重はこの柱以外の軸組材を全く経 由しない。棟束がからむ荷重点 10,11 からの経路も小屋組部材が 軸組に貫入した形態となっているため、部材数が少なくすまされて いる。この類型では、架構の一部ではあるが軸組と小屋組が未分化 な形態が残存している。

これに対して架構類型 $\mathrm{b}^{-}$は、下屋構造を多用しつつ、 $\mathrm{a}^{-}$と同様
に部材数を減らしたものである。例として掲げた堀口家住宅を見る と、平側の上屋境では荷重点 12 から上屋柱 $\mathrm{L}$ への経路 $\mathrm{Y} 2$ のよう に標準型に近い支持形式が見られるが、妻側では荷重点 13 から下 屋柱 $\mathrm{m}$ に至る経路 $\mathrm{YZx} 2$ のように、桁受けと叉柱を併用し著しく 部材数を減らしているものや、荷重点 14 から下屋柱 $\mathrm{n}$ に至る経路 YZxyz6 のように、釿梁を活かした技法も見られる。この類型では、

$\mathrm{a}^{-}$とは異なり、軸組と小屋組は明確に分離しているが、軸組に湾曲 材を巧妙に用いることで下屋構造を実現している。

前二者とは反対に、所要の移動方向数を得るために過㮃な部材を 費やした架構形式を挙げる。架構類型 $\mathrm{a}^{+}$は、 $\mathrm{a} 0$ と同様に上屋構造 を堅持したものである。例として揭げた佐伯家住宅では、荷重点 15 から上屋柱 $\mathrm{O}$ に至る経路 $\phi 3$ に $\mathrm{a} 0$ と同等の素朴な構法が見られる が、荷重点 16 から上屋柱 $\mathrm{P}$ への経路 $\phi_{5}$ において、荷重移動がな いにもかかわらず、京呂と重ね梁により、標準型より 3 部材多く 費やしている。また、妻側の荷重点 17 から上屋柱 Q に至る経路 YZ6 では、小屋組の受け口を桁受けとして標準型に比べ 1 部材省かれ ているが、京呂、重ね梁、管柱の併用により費される部材の合計は 多くなっている。この架構形式を指す呼称「枠の内」では、まさに 枅形に積層した上屋構造の枠の内側に空間が擁されている5)。

一方、架構類型 $\mathrm{b}^{+}$は、 bo と同様に下屋構造が発達し、なおかつ 多数の部材を費して小屋組の荷重を支持する形式である。例として 揭げた山下家住宅では、荷重点 18 から上屋柱 $\mathrm{R} へ$ へように単純な 経路 $\phi 3$ もあるが、複雑な経路の方がはるかに多い。下部空間の柱 を抜くために梁組が覆い被さるように配され、このような形状は「ク モデ」と呼ばれている 6)。上屋隅の荷重点 19 から下屋柱 $\mathrm{s}$ に至る 経路 Zxyz9 では、上屋における京呂、重ね梁、そして下屋にも京 呂が用いられ、標準型よりも 3 部材多く費やしている。また、荷 重点 20 から下屋柱 $\mathrm{t}$ に至る経路 Zxyz8 は、下屋およびそのさらに 外側の又下屋まで空間を拡張するために二重の十字梁が組まれてい るが、釿梁が用いられているため、標準型よりも 2 部材多い経由 部材数にとどまっている。

(3) 架構形式の極相のモデル化

以上の各例に見られるように、実際の架構では様々な構法が複合 しているため、上に挙げた類型の架構原理を、実例により必ずしも
表-2 荷重到達領域と経由部材数による架構類型の抽出

\begin{tabular}{|c|c|c|c|c|c|c|c|c|c|c|c|c|}
\hline \multirow{2}{*}{\begin{tabular}{|l|} 
住宅 \\
名称
\end{tabular}} & \multirow{2}{*}{$\begin{array}{c}\text { 全経路数 } \\
N \\
N\end{array}$} & \multicolumn{3}{|c|}{ 到達点による経路数内欺 } & \multicolumn{7}{|c|}{ 㟳準型 $(T=d+2)$ に対する経由部材数の多毒による経路数内部 } & \multirow[b]{2}{*}{ 架㩇類型 } \\
\hline & & \begin{tabular}{|r|} 
上屋 \\
$\mathrm{nc}$ \\
\end{tabular} & \begin{tabular}{|l|} 
下屋 \\
n。 \\
\end{tabular} & $\begin{array}{c}\text { 下屋到達橆 } \\
\mathrm{n} 。 / \mathrm{N}\end{array}$ & $(6=6)$ & $8 \%$ & $\begin{array}{c}T-1 \\
(t=d+1)\end{array}$ & $\begin{array}{c}T \pm 0 \\
(t=d+2)\end{array}$ & $\begin{array}{c}T+1 \\
(t=d+3)\end{array}$ & $\begin{array}{c}T+2 \\
(t=d+4)\end{array}$ & $(1,+45)$ & \\
\hline 古井* & 26 & 26 & 0 & 0.000 & \% & $\%$ & 8 & 18 & - & - & \% & ao \\
\hline 上野* & 34 & 34 & 0 & 0.000 & 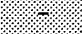 & 8. & - & 29 & - & - & \% & $a-$ \\
\hline 泉 & 154 & 79 & 75 & $\underline{0.487}$ & . & 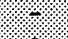 & 8 & 36 & 90 & 20 & \% & bo \\
\hline 坜川 & 50 & 29 & 21 & $\underline{0.420}$ & 4 & 8 & 12 & 25 & 2 & 5 & \% & $b-$ \\
\hline 椎名 & 124 & 71 & 53 & $\underline{0.427}$ & \% & $\%$ & 22 & 75 & 19 & 5 & 3 & $b+$ \\
\hline 北村 & 67 & 40 & 27 & $\underline{0.402}$ & \% & \% & 4 & 20 & 23 & 20 & \% & bo \\
\hline 春原 & 65 & 49 & 16 & 0.246 & \% & \% & 8 & 43 & 12 & 2 & $\%$ & ao \\
\hline 堀口* & 75 & 37 & 38 & 0.507 & 9 & 5 & 30 & 25 & 5 & 1 & $\%$ & $b-$ \\
\hline 牧村* & 109 & 68 & 41 & $\underline{0.376}$ & $\%$ & . & 3 & 21 & 64 & 21 & $\%$ & bo \\
\hline 佐藤 & 32 & 22 & 10 & 0.313 & \% & \%. & 1 & 9 & 18 & 4 & $\%$ & ao \\
\hline 座主 & 77 & 51 & 26 & 0.338 & $\%$ & \% & 22 & 31 & 19 & 5 & $\%$ & bo \\
\hline 江向 & 67 & 47 & 20 & 0.299 & \% & \% & 22 & 21 & 16 & 8 & 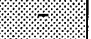 & 20 \\
\hline 憍本 & 148 & 50 & 98 & $\underline{0.662}$ & 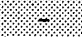 & \% & 11 & 39 & 45 & 42 & 11 & b+ \\
\hline 宮地 & 51 & 37 & 14 & 0.275 & \% & \% & 6 & 20 & 18 & 7 & \% & ao \\
\hline 山下* & 115 & 39 & 76 & $\underline{0.661}$ & . & \% & 15 & 35 & 46 & 11 & 8 & $b+$ \\
\hline 佐伯* & 135 & 121 & 14 & 0.104 & . & . & - & 44 & 54 & 30 & $1 \%$ & $a+$ \\
\hline 山口 & 179 & 72 & 107 & $\underline{0.598}$ & \% & \% & 25 & 67 & 67 & 17 & 3 & $b+$ \\
\hline 龧原 & 91 & 56 & 35 & 0.385 & 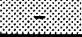 & 样 & 4 & 38 & 27 & 14 & 8 & b+ \\
\hline Et & 1599 & 928 & 671 & 0.419 & 1) & 12 & 201 & 596 & 525 & 212 & 10 & \\
\hline
\end{tabular}

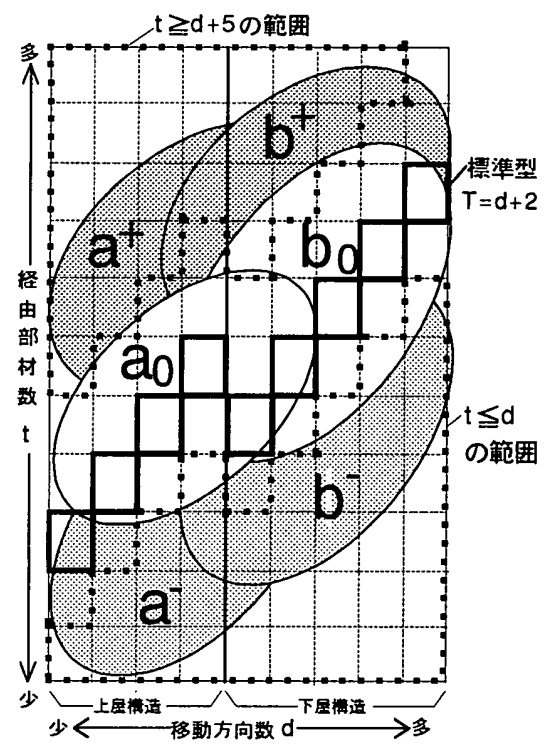

図-6 架構類型の位置づけ 


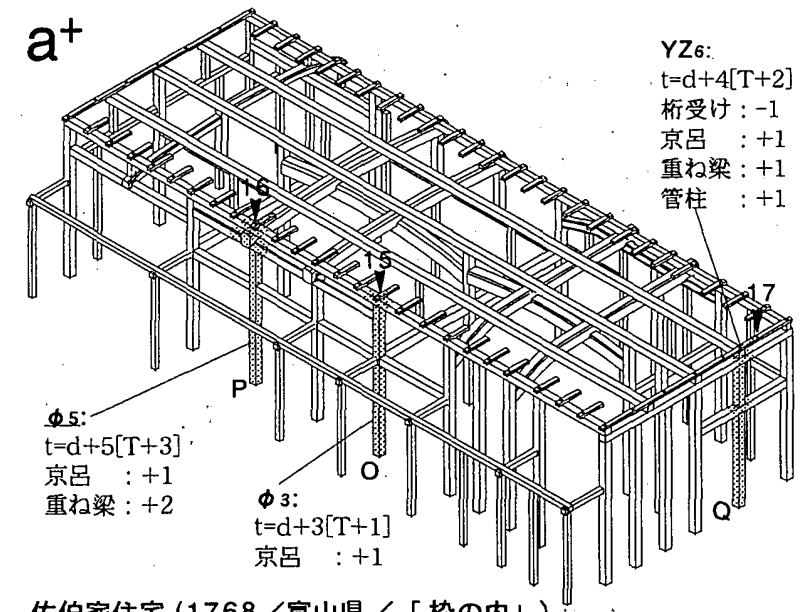

佐伯家住宅 $(1768$ /富山県/「枠の内」)

$35 Y_{3}+X_{Y Z}+8 Z_{2 x y z 7}+10 \phi 3+5 \phi 4+14 Y_{4}+11 Y_{5}+17 Y Z_{5}$
$+12 Z_{6}+9 \times Y Z 6+2 Z \times 5+2 Z \times 6+2 Z \times y z 7 \pm 2 \phi 5+5 Y Z 7$ [計 135 経路]

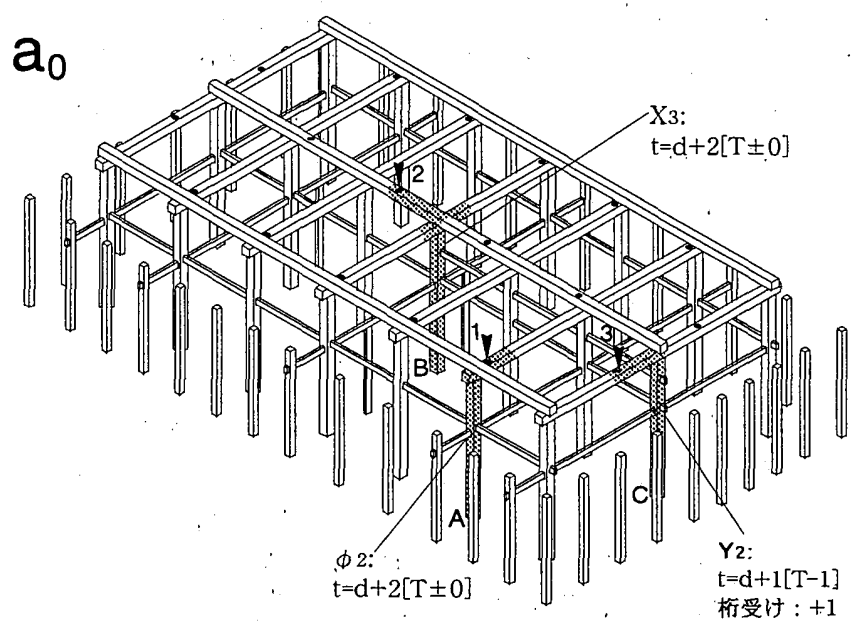

古井家住宅 (16 世紀後半/兵庫県)

$\left(8 Y_{2}\right)+10 \phi \dot{2}+\left(8 X_{3}\right)$ [計 26 経路]

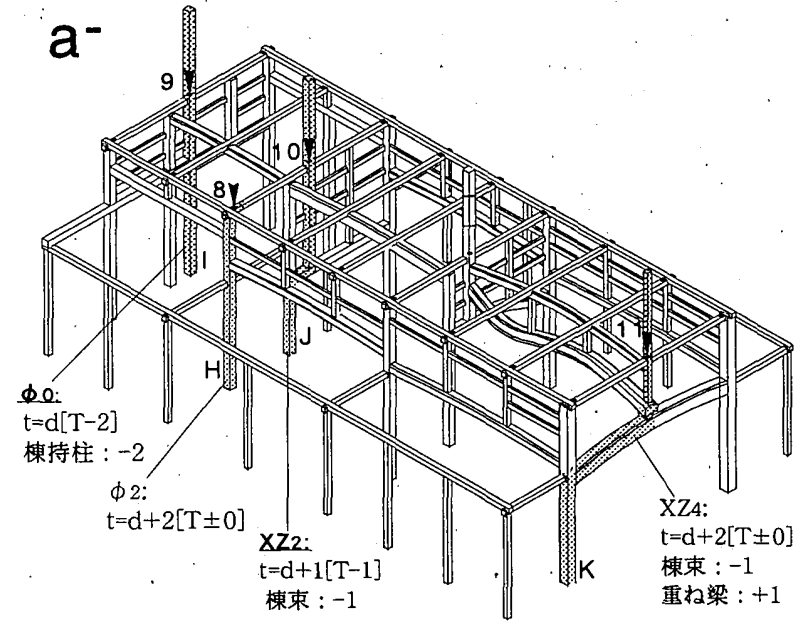

上野家住宅 (17 世紀初期/山梨県/「四つ建て」) $\left(\phi 0+4 X Z_{2}\right)+9 \phi 2+18 Z_{4}+\left(2 X Z_{4}\right)$. [計34経路]

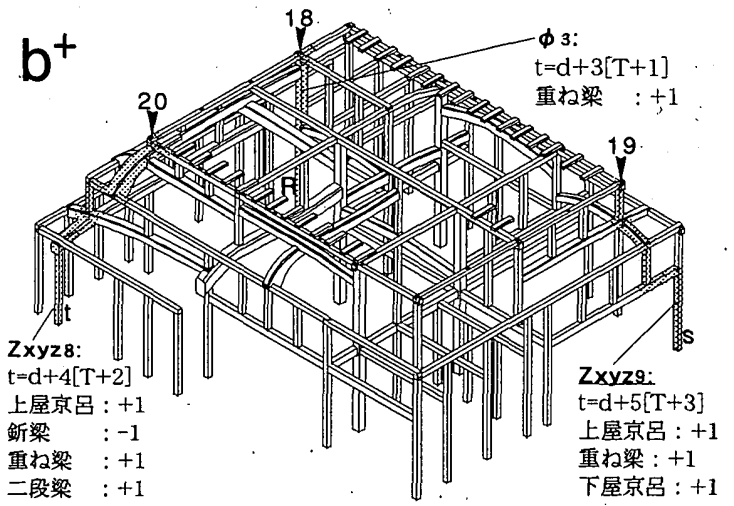

山下家住宅 (18世紀中期 /福井県／「釒建て」〈大浦型〉) $4 Y 2+X Y Z 4+2 Y Z X 4+8 Y Z x y 5+4 Y 3+8 Y Z 7+8 X Y Z 5+11 Y Z x 5+4 Y Z x y z 7$ $+\phi 3+Y 4+X Z 5+3 Y Z 2+5 \times Y Z 6+2 X Y Z 7+2 Z \times 5+4 Y Z \times 6+Y Z \times 7+2 Z \times y 6$ $+8 Z \times y z 8+Y Z x y 7+26 Y Z \times y z 8 \pm X Y Z 8+Y Z \times 8+6 Z \times y z 2$ [計 115 経路]

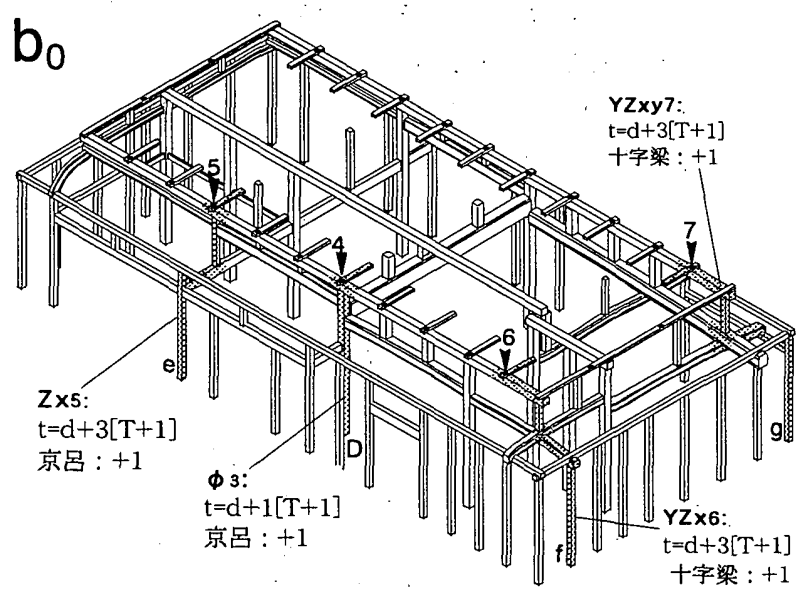

牧村家住宅 (18 世紀初期/岐阜県/「鳥居建て」)

$Y Z \times 4+2 Y Z \times y 5+8 Y 3+4 Y Z 4+3 X Y Z 5+6 Y Z x 5+4 \phi 3+X Z 5+30 Y Z 5$

$+13 Y Z 6+X Y Z 6+4 \times Y Z 7+Z \times 5+7 Y Z \times 6+4 Y Z \times 7+20 Y Z \times y 7$ [計 109 経路]

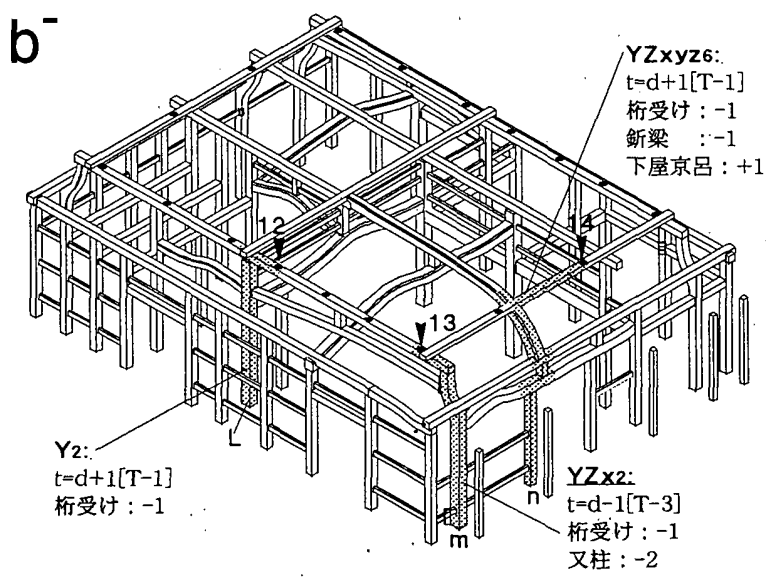

堀口家住宅 (18 世紀初期 /福井県 / <越前 I 型>)

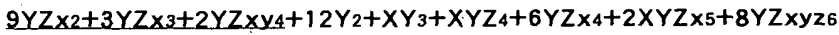
$+4 Y_{3}+6 Y_{4}+8 X Y Z_{5}+7 Y_{2 x}+Y_{4}+Y_{5}+2 Y_{5}+X Y_{6}+Y Z X_{6}[$ [計75経路]

住宅名称の下には経路集計式を多項式で示した。多項式の表示形式は、移動方向数 $\mathrm{d} に$ 对する経由部材数坆関係により、太字加つアンターラインはtくd+lまたはt 太字は $\mathrm{t}=\mathrm{d}+1, \mathrm{~d}+3, \mathrm{~d}+4$ 、細字はt=d+2[慓準型T]が成り立つものをそれそれ示す。なお、小屋束からの経路は( )内に示した。 
明確に示し得ない。そこで、各々の原理が顕著に表れているような 架構形式を極端化して図説したものが図-8である。

A 0 から $\mathrm{B} 0$ に至る系列は、小屋組の荷重を支持する構法が、梁・ 桁・束を順に組み合わせ、一部材につき一方向の荷重移動を供する 原則に沿って発達しているものである。この系列は、下部空間の下 屋への広がりと架構の複雑さが、適度にバランスして成立している といえる。

A`から B-に至る系列は、小屋組の荷重を支持するために最小限 の部材数でまかなおうとする傾向が共通している。A-における棟 持柱構法は、長大な通直材を活かす発想である。これに対し、Bでは叉柱や釿梁のような湾曲した長材を活用する発想に特徴があり、 巧妙で軽快な手法により成り立つ構成方法といえる。この系列は、 主として柱勝ちあるいは柱が優位であるような構法が対応している。

$\mathrm{A}^{+}$から $\mathrm{B}^{+}$に至る系列は、下部空間の自由度を確保するために、 必要以上に多くの部材を費して上部荷重を支持しているものである。 $\mathrm{A}^{+}$が上屋構造の枠組のなかで部材を重ねたものであるのに対し、 $\mathrm{B}^{+}$ は、幾重もの組梁を下屋に張り出した展延性のある形式である。こ の系列に属する類型は、いずれも梁勝ちあるいは梁組が卓越する構 法が対応している。
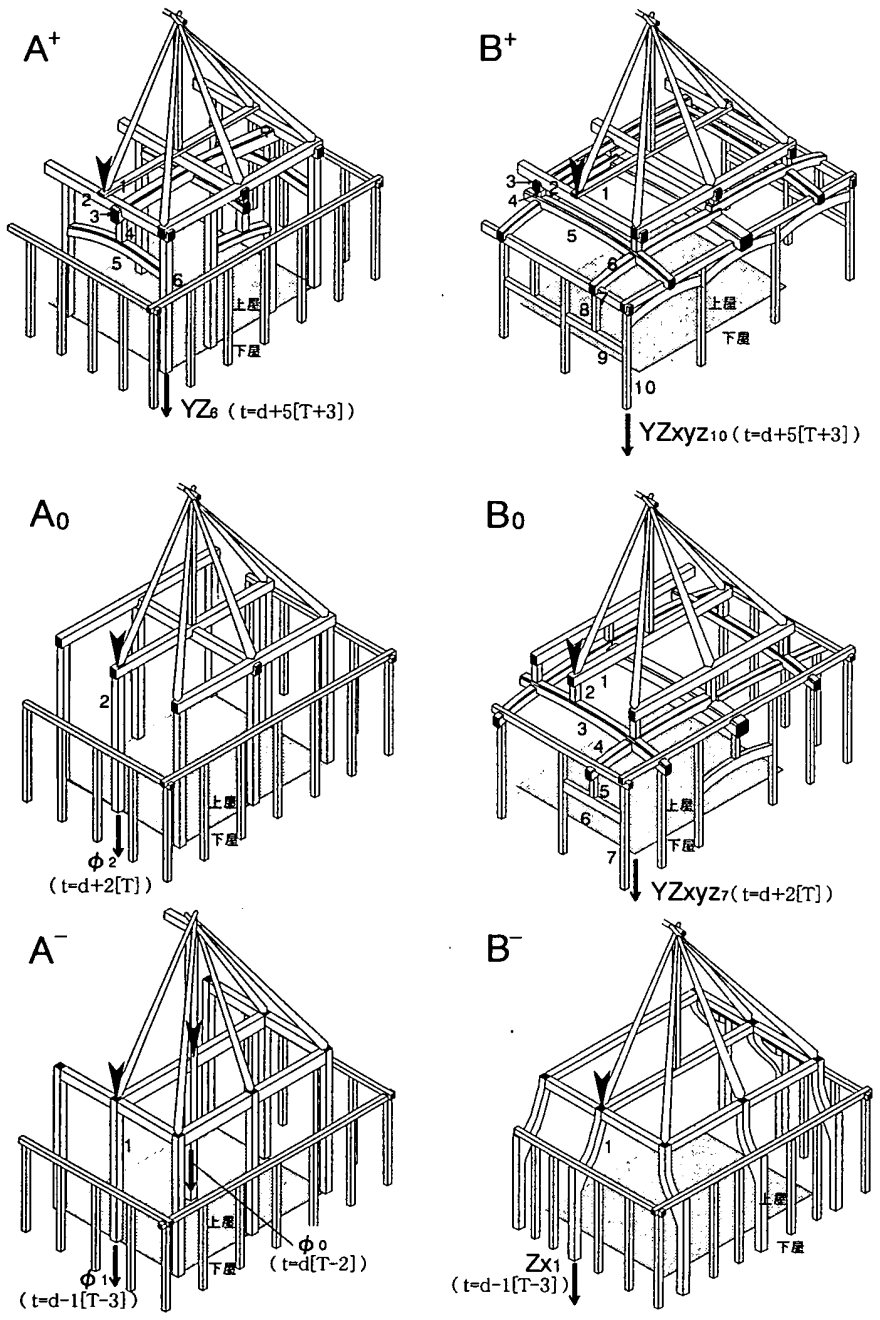

図-8 極相のモデル化

\section{5. 結}

本編は、伝統的民家における小屋組の荷重の支持形式を把握す るために、荷重経路という概念を設定し、荷重の伝達方向の多様性 と、到達点までに費される部材数の関連性を考察したものである。

個々の荷重経路の分析においては、荷重の移動方向に変化が生 じるような部材配置を、上屋・下屋の関係から序列化し、また荷重 が経由する部材数の多寡を生じさせている構法を抽出した。一方、 荷重経路の集合形式により各棟の架構を類型化した結果、上屋・下 屋間の空間的な展開性と、重層した梁、桁、束に見られるような架 構部材の複雑性の双方が、架構形式を特徵づけていることがわかっ た。さらに、そこから抽出される架構原理の極相を示した。実際の 民家の架構は、これらの極相の中間的な形式として存在する場合が 多いが、こうした極相が局部的にであれ発現することが、地域に固 有な架構法として表われているものと思われる。

本研究で提示した方法論は、従来の民家研究においてしばしば注 目されてきた下屋構造の進展という観点のみならず、荷重支持に費 される部材の多寡により架構の複雑性を包括的に評価しようとした ものである。この評価方法は、複雑さと多様化を極めているがゆえ にその質的把握が困難であると考えられてきた民家の空間性 クを解 析する手がかりとなるであろう。

注

1) 文献 1

2) 文献 2

3) 領域と方向性を示す記号 X, Y, Z, x, y, z は拙稿・文献 1,pp.118-120 におい て行った定義による。

4）上屋權造、下屋櫣造の概念については、拙稿・文献 3 に拈いて既往研究を 検討した結果に立脚し、文献 2 に挹ける横妿材の位相の分類に適用している。

5) 文献 4 によれば「枠の内」は「室の周囲に太い柱を配し、柱間を差し物で 緊結し、上方には太い梁組をつくる。梁組は井桁になるものが多い。とさ れているが、下屋構造の有無については言及されていない。文献 5,p.134に は、「枠の内」にも地域性があり、上屋で完成するものと、下屋を取り込ん でいるものとがあることが指摘されている。

6) 山下家住宅の属する大浦型と類似の架構形式とみられる滋賀県高島郡マキ 町在原集落のなかで最も古く原形をとどめている橋本家住宅の当主・橋本彦 一氏加のヒアリングによる。「蜘蛛の手」の意か。なお、梁組が二段にな れば「重ねつモテ」と呼ぶ成。

7) 日本建築に扩ける民家の空間性に関する所見として、文献 $6, p .539$ には「量 的には比較にならないほ程の巨大な厚みであるにもかかわらず、民家はその 質的把握が困難であるため現代建築との連帯感が甚だ稀薄である」とあり、 文献 7,p.69には「民家は自然現象に近いことを指摘したが、それは、法則 的な造形の文法を取り出すことがきわめてむすかしいからである」という指 摘がある。また文献 8, p.44に「目本建築にはあるところですっきり割り切 って、きれいに清算してしまっている空間がある。(中略非常にどろどろし た民家のようなものも当然あるけれども、それとは違う、非常にすっきりし た空間がある」という西和夫の指摘があり、いずれも日本建築における民家 空間の特殊性を示唆していると思われる。

参考文献

1) 塻江亭 : 日本の伝統的民家の架構配置に関する分析述語の定義 木造軸組楧 法の空間構成に関する方法論的研究 その 1 ，日本建築学会計画系論文集第 501 号 pp.117.124,1997.11

2) 堀江亨 : 日本の伝統的民家の軸組架楧における横架材配置の類型化 木造軸 組構法の空間榗成に関する方法論的研究 その 2 , 日本建築学会計画系論文 集第 511 号, pp.123-130, 1998.9

3）堀江享，八木幸二:日本の伝統的民家における下屋構造の複雑さからみた軸 組架楧の類型化，日本建築学会計画系論文集第 499 号, pp.81-88, 1997.9

4) 日本建築学会民家語军集録部会編:日本民家語彙解説辞典，日外アソシエーツ， 1993.9

5) 玉置伸俉 : 北陸地方における農家住宅の変容過程に関する研究，財)住宅総 合研究財団, 1992.6

6) 篠原一男 : 非開放的な空間について 日本建築の方法(3),日本建築学会論文 報告集第 60 号 pp.537.540, 1958.10

7) 篠原一男 : 住宅建筑，紀伊国屋書店，復刻版, 1994.1

8) 相田武文, 出江寬, 伊東豊雄, 西和夫, 門内弾行 : 伝統の継承・变換・創造 としてのデザイン[作品解析討論会],建築雑誌,pp.38-45, 日本建築学会, 1993.5 